\title{
Isolating of a putative glyceraldehyde-3 phosphate dehydrogenase (GAPDH) from Calophyllum brasiliense, an important tropical forest tree
}

\author{
By C. M. Patreze ${ }^{1), *)}$, D. B. Felix ${ }^{2)}$, F. R. ScaranO ${ }^{3)}$ and M. Alves-Ferreira ${ }^{2)}$
}

(Received $7^{\text {th }}$ July 2011)

\begin{abstract}
Calophyllum brasiliense Cambess. has characteristics that made it an excellent candidate model for ecogenomics in rain forest trees such as widespread natural occurrence and geographical patterns of adaptive genetic variation. Besides, it is also becoming a popular species for reforestation efforts in Brazil. Although, very little is known about its genetic diversity and the molecular mechanisms involved genetic adaptation traits. The first difficulty in launching genetic studies in a wild wood species is the lack of an optimized protocol for RNA and DNA isolation. In this work we built the essential framework for molecular genetics research with C. brasiliense comparing four distinct methods of RNA extraction from of three different tissues: leaves, stems and roots. We also were successful in the isolation of genomic DNA by an optimized CTAB method. Finally, degenerated oligonucleotide primers were designed for isolating of the glyceraldehyde-3 phosphate dehydrogenase $(G A P D H)$ gene of $C$. brasiliense from the corresponding gene in closely related species. This gene is commonly used in plants as reference in expression gene analysis by Reverse Transcription Polymerase Chain Reaction (RT-PCR). Primers for RT-PCR were designed based on partial sequence obtained using degenerate primers designed. The optimized methods of RNA and DNA extraction combined with the identification, isolation and specific primer design for RT-PCR of a traditional Reference Gene provide the essential framework for molecular genetics research with $C$. brasiliense.
\end{abstract}

Key words: Calophyllum brasiliense; gene expression; nucleic acid extraction; ecogenomics.

\section{Introduction}

Calophyllum brasiliense Cambess. (Clusiaceae) is a hardwood tree claimed to be an alternative to mahogany (CARVAlHO, 1994), which is almost exclusive to floodprone sites throughout a large geographic range in the neotropics (OLIVEIRA-FILHO and RATTER, 1995). For instance, in Amazon flooded forests this large tree is subjected to six months of deep river flooding and eventual submersion (e.g., KING, 2003), whereas in the

\footnotetext{
1) Department of Botany, Federal University of Rio de Janeiro State, Centro de Ciências Biológicas e da Saúde, 22290240 Rio de Janeiro, Brazil.

2) Department of Genetics, Federal University of Rio de Janeiro, Centro de Ciências da Saúde, 21949900 Rio de Janeiro, Brazil.

$\left.{ }^{3}\right)$ Department of Ecology, Federal University of Rio de Janeiro, CCS, IB, BP 68020, 21941-970 Rio de Janeiro, Brazil.

*) Corresponding author: CAmila Maistro Patreze. Universidade Federal do Estado do Rio de Janeiro, Instituto de Biociências, Departamento de Botânica. Av. Pasteur, $\mathrm{n}^{\circ} 458$, Urca, sala 409 , 22290240 - Rio de Janeiro, RJ - Brasil. Tel. +55 2122445681 , Fax +55 2122756059 . E-Mail: ㅁpatreze@hotmail.com.
}

swamp forests of southeast Brazil it undergoes almost permanent root flooding due to water table rises (SCARANO et al., 1997; DUARTE et al., 2005). Moreover, there is evidence that even within a small geographic range ecological behavior can be broadly variable among individuals of Calophyllum brasiliense. For example, FISCHER and Dos SANTOS (2001) have found differences in demography, sexual expression, phenology and flower and fruit production for this species among three contiguous habitats found in the lowlands within the domain of the Brazilian Atlantic rain forest of southeast Brazilunflooded forest, freshwater-flooded forest and mangrove in an old-growth estuarine forest.

Thus, geographical patterns of adaptive genetic variation are expected for $C$. brasiliense that turns it into an excellent candidate for studying the molecular mechanisms involved in genetic adaptation traits, especially those related to oxygen deprivation in consequence of flooding. The unveiling of the mechanisms of adaptation through the incorporation of genomic tools, i.e. ecogenomics, has poplars (Populus spp.) and conifers (e.g. Pinus spp., Pseudotsuga menziesii and Cryptomeria japonica) (FEDER and Mitchell-Olds, 2003; NEALE and SAVOLAINEN, 2004), as typical model species in forestry. While trees are ideal organisms to unveil the molecular basis of population adaptive divergence in nature (GONZÁlEZ-MARTÍNEZ et al., 2006), there are still no model species from the rain forests, and we expect that C. brasiliense could fill this gap. Moreover, its current use in commercial (HoLL, 1998) and ecologically-oriented (BozELLI et al., 2000) reforestation efforts in Brazil highlight the importance of this tropical tree.

A first step to genetic analysis is the isolation of plant RNA and DNA, which are particularly challenging tasks, in particular from uncultivated or woody species. One of the major issues with plant nucleic acid isolation is the presence of problematic biomolecules, such as polyphenolic compounds and polysaccharides that interfere in the quantification and also trigger degradation of nucleic acids. Thus, extracting RNA and DNA from plant tissues often requires adaptation of existing protocols or new procedures. This is particularly true for woody species as it was shown for species of Pinus (Chang et al., 1993; Claros and Cánovas, 1998), Malus (GASIC et al., 2004), Prunus (MEISEL et al., 2005), Litchi (WANG et al., 2008), among others.

The gene expression analysis for species whose genomes are not sequenced is a critical challenge. The advent of the Reverse Transcription Polymerase Chain Reaction (RT-PCR) technique for the measurement of gene expression has allowed an accurate determination of the expression levels of target genes when compared 
to Northern blot analysis (DEAN et al., 2002). This former technique is time-consuming and requires a large quantity of RNA. Semi-quantitative gene expression data are often normalized to the expression levels of control or so-called "housekeeping" genes that show remain constant gene expression levels in distinct tissues under investigation. Glyceraldehyde-3-phosphate dehydrogenase $(G A P D H)$, a classical glycolytic enzyme, is involved in cellular energy production and has important housekeeping functions. The expression of GAPDH has been proved to be highly stable in different organs and experimental condition of several plant species as Saccharum sp. (ISKANDAR et al., 2004), Vitis vinifera (REID et al., 2006); Arabidopsis thaliana and Thlaspi caerulescens (KÜPPER et al., 2007); Lolium perenne L. (MARTIN et al., 2008); Coffee arabica (CRUZ et al., 2009); Gossypium hirsutum (ARTICO et al., 2010). In spite of its growing importance, there are not sequences of C. brasiliense available in any public database up to now by our knowledge. We consider that GAPDH gene might be also a good reference gene for gene expression analysis, therefore we focus on its isolation and characterization in C. brasiliense.

The use of degenerate oligonucleotide primers is one of the established methods employed to isolate genes from non-model plants, such as C. brasiliense (LÖFFERT et al., 1998). Recently, the use of degenerate primers was successful employed to isolated genes from some species such as Elaeis guineensis (OMAR et al., 2008); Trifolium repens L. (TANG et al., 2010); Vitis amurensis (KISELEV and Dubrovina, 2010). MARTIN et al. (2008) isolated nine candidates to housekeeping gene, including $G A P D H$, from Lolium perenne L. using the degenerated primers methodology. However, none gene from $C$. brasiliense has been described using this method up to now.

In this work we ascertained the best method for RNA isolation from different $C$. brasiliense tissues after testing four distinct methods. We also described an adapted protocol for DNA isolating from $C$. brasiliense based on a method developed for DNA isolation from eucalyptus ssp. (FERREIRA and Grattapaglia, 1995). The methods described here are efficient for RNA and DNA extraction from different tissues and they provide a good quality material for enzymatic assays, such as cDNA synthesis or restriction enzyme reactions. In addition, we isolated the $C$. brasiliense GAPDH gene, a traditional reference gene, a crucial step for performing gene expression analysis by RT-PCR or real-time PCR.

\section{Materials and Methods}

\section{Plant materials}

Seedlings of $C$. brasiliense were grown in a greenhouse at a thermo period of $25 / 20 \pm 2{ }^{\circ} \mathrm{C}$ and natural conditions of luminosity in the Federal University of Rio de Janeiro, Brazil. Leaves, stems and roots of two plants, four months old, were collected, immediately frozen in liquid nitrogen and subsequently ground into fine powders using a mortar and a pestle in liquid nitrogen. The resulting tissue powder was stored at $-80^{\circ} \mathrm{C}$ until use.

\section{DNA isolation}

The total DNA from leaves, stems and roots were extracted using an optimized method adapted from a protocol previously described by FERREIRA and GRATTAPAGLIA (1995).

The plant tissue was ground with mortar and pestle to a fine powder in the presence of liquid nitrogen. The powder $(300 \mathrm{mg}$ ) was transferred to a microtube with $900 \mu \mathrm{L}$ of extraction buffer containing all reagents described by FERREIRA and GRATTAPAGLIA (1995) at the same concentrations, except for CTAB (hexadecyltrimethylammonium bromide) and 2 - $\beta$-mercaptoethanol, which the concentration were increased to 2 and $1 \%$, respectively. Each sample was mixed by vortexing the tube, which was then incubated at $65^{\circ} \mathrm{C}$ in a water-bath for 30-60 min with occasional shaking after each 10-15 min. Chloroform/isoamylalcohol (24:1, v/v) extractions were performed and the DNA was precipitated by addition of 0.1 volume of CTAB buffer (10\% CTAB, $1.4 \mathrm{M} \mathrm{NaCl}$ ) and homogenizing by inversion for $5 \mathrm{~min}$, followed by addition of $2 / 3$ volumes of isopropanol and incubation at $-20^{\circ} \mathrm{C}$ overnight. The sample was then centrifuged at $13,000 \mathrm{rpm}$ for $20 \mathrm{~min}$ at $4^{\circ} \mathrm{C}$. The pellet was washed two times with $1 \mathrm{~mL}$ of cold ethanol $70 \%$ for 3-5 min and once with $1 \mathrm{~mL} 95 \%$ of cold ethanol for 2-3 min. The DNA pellet was air-dried for $30 \mathrm{~min}$. The pellet was ressuspended in buffer TE $(10 \mathrm{mM}$ Tris- $\mathrm{HCl}$ ( $\mathrm{pH}$ 8.0), $1 \mathrm{mM}$ EDTA) for $30 \mathrm{~min}$ at room temperature. RNAse $(10 \mu \mathrm{g} / \mathrm{mL})$ digestion was performed by incubation at $37^{\circ} \mathrm{C}$ for $30 \mathrm{~min}$. The quality and yield of total DNA extracted from different tissues were assessed by gel analysis and NanoDrop, model ND-1000 spectrophotometer (NanoDrop Technologies; Wilmington, DE).

Four restriction enzymes were used to check the DNA quality for enzymatic manipulation: Pst I (octa-cutter) (Invitrogen), EcoRI (Invitrogen), HindIII (hexa-cutter) (Invitrogen) and HinfI (tetra-cutter) (Invitrogen). The enzymes were selected according to their frequency of sites in genomic DNA, an important characteristic for assessment of diversity using DNA-based techniques such as AFLP. Digestions were performed according to the manufacturer's recommendations for 2 hours at $37^{\circ} \mathrm{C}$. One microgram of each DNA sample extracted of C. brasiliense leaf, stem and root were used in the assays.

\section{RNA isolation protocols}

One-hundred milligrams of fresh plant tissues (leaves, stems or roots) were used in four different protocols. The extraction procedures - (1) Trizol ${ }^{\circledR}$ (Invitrogen); (2) RNeasy ${ }^{\circledR}$ Plant Mini Kit (Qiagen) and (3) - Invisorb ${ }^{\circledR}$ Spin Plant RNA Mini Kit (Invitek) were performed following the manufacturing's instructions. For all procedures, two biological replicates were prepared. A fourth method adapted from WANG et al. (2008) (4) was tested using $1 \mathrm{~g}$ of fresh tissue. The method reported by WANG and collaborators uses ethylenediaminetetraacetic acid (EDTA), N-lauroyl sarcosine sodium (LSS) in combination with cetyltrimethylammonium bromide (CTAB). Sodium borate and polyvinylpyrrolidone (PVP) under a deoxidized condition are used to remove secondary metabolites and other interfering compounds. The pro- 
cedure (4) was the following: $1 \mathrm{~g}$ of plant tissues was ground in liquid nitrogen and incubated in $5 \mathrm{~mL}$ extraction buffer containing $2 \mathrm{M} \mathrm{NaCl}, 25 \mathrm{mM}$ EDTA, $200 \mathrm{mM}$ Tris ( $\mathrm{pH} 8.0$ ), $20 \mathrm{mM}$ sodium borate, $2 \%$ PVP (mol wt 40,000), $2 \%$ CTAB (w/v), 1\% LSS (w/v), and $2 \% \beta$-mercaptoethanol $(\mathrm{v} / \mathrm{v})$ at $65^{\circ} \mathrm{C}$ in a water-bath shaker over 15 min with occasional shaking after each 5 min. Six milliliters of chloroform/isoamyl alcohol (24:1, v/v) were added into the mixture, and then mixed vigorously, followed by centrifuging at $14,000 \mathrm{rpm}$ for $15 \mathrm{~min}$ at $4{ }^{\circ} \mathrm{C}$. The resulting aqueous solution (upper phase) was transferred into another tube containing $8 \mathrm{~mL}$ of water-saturated phenol/chloroform/isoamyl alcohol (25:24:1, v/v, pH 4.5). The sample was mixed vigorously and then centrifuged at $11,000 \mathrm{rpm}$ for $10 \mathrm{~min}$ at $4{ }^{\circ} \mathrm{C}$; this step was repeated twice. The upper phase containing RNA was extracted with $8 \mathrm{~mL}$ chloroform/isoamyl alcohol (24:1, $\mathrm{v} / \mathrm{v})$ and then centrifuged at $11,000 \mathrm{rpm}$ for $10 \mathrm{~min}$ at $4{ }^{\circ} \mathrm{C}$. The upper phase was transferred into a fresh centrifuge tube and 0.8 volumes $(\sim 6 \mathrm{~mL})$ of $5 \mathrm{M} \mathrm{LiCl}$ (Vetec) were added. The mixture was incubated at $-20^{\circ} \mathrm{C}$ overnight, followed by centrifuging at $14,000 \mathrm{rpm}$ for 15 min at $4{ }^{\circ} \mathrm{C}$. The pellet was rinsed three times with $5 \mathrm{~mL}$ of cold $75 \%$ ethanol. The air-dried pellet was ressuspended in $200 \mu \mathrm{L}$ of TE and transferred into a microtube with $600 \mu \mathrm{L}$ absolute ethanol and $10 \mu \mathrm{L} 3 \mathrm{M} \mathrm{NaAc}$ (pH 5.2) at $-20^{\circ} \mathrm{C}$ for $30 \mathrm{~min}$. The samples were centrifuged at $14,000 \mathrm{rpm}$ for $15 \mathrm{~min}$ at $4^{\circ} \mathrm{C}$. The pellet was air-dried and finally ressuspended in $50 \mu \mathrm{L}$ of Milli-Q sterile water.

\section{RNA purification and cDNA synthesis}

After extraction, RNA samples were treated with $0.5 \mathrm{u} / \mu \mathrm{g}$ RNA of RNase-free DNase I (Invitrogen) for RTPCR as follows: samples were incubated (10 $\mu \mathrm{g}$ RNA) at $37^{\circ} \mathrm{C}$ for 15 min with $5 \mathrm{U}$ of the enzyme and $10 \mathrm{X}$ buffer (200 mM Tris $\mathrm{HCl} \mathrm{pH} 8.3 ; 500 \mathrm{mM} \mathrm{KCl} ; 25 \mathrm{mM} \mathrm{MgCl}_{2}$ ). Milli-Q sterile water $(450 \mu \mathrm{L})$ and phenol $(500 \mu \mathrm{L})$ were added into the tube and mixed by inversion. Each sample was centrifuged at 10,000 rpm for $10 \mathrm{~min}$ and the supernatant was transferred into a new tube containing one volume of chloroform $(\sim 500 \mu \mathrm{L})$. The sample was mixed by inversion and centrifuged as previously described. The supernatant was carefully transferred into a new tube and the RNA was precipitated with 0.1 volume of sodium acetate $3 \mathrm{M}$ and 2 volumes of $100 \%$ ethanol for 1 hour at $-20^{\circ} \mathrm{C}$. After centrifugation at $12,000 \mathrm{rpm}$ for 20 min, the supernatant was discarded. The sample was rinsed with $500 \mu \mathrm{L} 70 \%$ ethanol and centrifuged at $10,000 \mathrm{rpm}$ for $5 \mathrm{~min}$. The supernatant was then discarded and the pellet was air-dried for $30 \mathrm{~min}$. The RNA was ressuspended in $15 \mu \mathrm{L}$ of Milli-Q sterile water. RNA integrity was assessed by electrophoresis on $1 \%$ nondenaturing agarose gel. The purity and yield of total RNA extracted from different tissues were measured by the NanoDrop, model ND-1000 spectrophotometer (NanoDrop Technologies; Wilmington, DE).

cDNAs were synthesized by adding $50 \mu \mathrm{M}$ of oligo (dT24V) and $10 \mathrm{mM}$ of each deoxyribonucleoside 5'triphosphate (dNTPs) to $2 \mu \mathrm{g}$ of total RNA. This mixture was incubated at $65^{\circ} \mathrm{C}$ for $5 \mathrm{~min}$, and briefly chilled on ice. First Strand Buffer, $20 \mathrm{mM}$ of dithiothreitol (DTT) and 200 units of Superscript III (Invitrogen) were added to the prior mixture and the total volume $(20 \mu \mathrm{L})$ was incubated at $50^{\circ} \mathrm{C}$ for $1 \mathrm{~h}$ following fabricant instructions. Inactivation of the reverse transcriptase was done by incubating the mixture at $70^{\circ} \mathrm{C}$ for $15 \mathrm{~min}$.

\section{Isolation of specific sequence of GAPDH gene from C. brasiliense}

Thirty five sequences related to plant $G A P D H$ were retrieved from GenBank databases and aligned using Clustal W multiple alignment. After the alignment, nine sequences were selected for primer design, all belonging to eurosid group, since $C$. brasiliense is an eurosid member. Degenerated primers were designed using SCPrimer program (JABADO et al., 2006) with the total number species, i.e. maximum degeneracy of 100 . Design criteria for primers were as follows: 18-32 nt in length, Nearest Neighbor Tm $50-65^{\circ} \mathrm{C}$ (optimum $60^{\circ} \mathrm{C}$ ) with sodium concentration of $50 \mathrm{mM}, 40-60 \%$ GC, maximum allowed hairpins of 8 nucleotides, a maximum homopolymeric run of 4 nucleotides, no mismatches allowed in 3 pentamer, maximum of three mismatches to any targeted template and an amplicon size of 150-300 nucleotides. Primer pairs with melting temperatures within $3^{\circ} \mathrm{C}$ of each other were selected. To visualize the position of degenerate primers, the GAPDH nucleotide sequences were aligned with the sequences forward and reverse of primers using the software Mega, version 3.0 (KUMAR et al., 2004).

The PCR was done in a total volume of $25 \mu \mathrm{L}$ using $1 \mu \mathrm{L}$ of cDNA from stem of $C$. brasiliense, $0.2 \mu \mathrm{M}$ of each primer (F: 5' HGAYAAGGAMAARGCTGCTGC 3'; R: 5' ATCVACRGTDGGNACACGGA 3') $200 \mu \mathrm{M}$ of each dNTP, 1X PCR Buffer (Fermentas), 0.25 units of Taq DNA polimerase (Fermentas). Reaction mixtures were incubated for $5 \mathrm{~min}$ at $95^{\circ} \mathrm{C}$, followed by amplification 40 cycles of $30 \mathrm{~s}$ at $95^{\circ} \mathrm{C}, 45 \mathrm{~s}$ at $55^{\circ} \mathrm{C}$ and $120 \mathrm{~s}$ at $72^{\circ} \mathrm{C}$; followed by an elongation step at $72^{\circ} \mathrm{C}$ for $7 \mathrm{~min}$, in a Mastercycler personal termocycler (Eppendorf). The PCR product generated with designed primer was cloned into pGEM-T Easy Vector and validated by sequencing. Sequencing reactions were performed for each clone (100 ng $\left.\mu \mathrm{L}^{-1}\right)$ using the Perkin Elmer Biosystems Big Dye Terminator Sequence Reaction kit (Perkin Elmer, Foster City, CA) in the MegaBACE 1000 System (GE-Amersham Biosystem, Chalfont St. Giles, UK). BLAST analysis was performed to verify the similarity with other GAPDH.

To examine the structural relationship between $G A P D H$ from $C$. brasiliense and GAPCP-1 from A. thaliana, the genomic full length and CDS sequences of this gene from $A$. thaliana were retrieved from TAIR database and aligned with the $C$. brasiliense sequence cloned. We suggest the name CbrGAPDH for the sequence of $C$. brasiliense $G A P D H$ cloned.

\section{Reverse transcription polymerase chain reaction (RT-PCR)}

Reaction mixtures contained $1 \mu \mathrm{L}$ of $\mathrm{cDNA}, 0.2 \mu \mathrm{M}$ of each primer, $200 \mu \mathrm{M}$ of each dNTP, 1X PCR Buffer (Fermentas), 0.25 units of Taq DNA polimerase (Fermentas), in a total volume of $25 \mu \mathrm{L}$. Reaction mixtures were incu- 
bated for $5 \mathrm{~min}$ at $94^{\circ} \mathrm{C}$, followed by $20,25,30$ and 40 amplification cycles of $30 \mathrm{~s}$ at $94^{\circ} \mathrm{C}, 45 \mathrm{~s}$ at $60^{\circ} \mathrm{C}$ and $120 \mathrm{~s}$ at $72^{\circ} \mathrm{C}$; followed by an elongation step at $72^{\circ} \mathrm{C}$ for $7 \mathrm{~min}$. PCR reactions were performed in a Mastercycler personal termocycler (Eppendorf). Two primers were designed to amplify a specific region of this gene: 5'-TTGTGGGTGTCAACGAGAAG-3' (forward) and 5'CCCTCAACTATGCCAAACCT-3' (reverse). The amplification products were visualized on a $1 \%(\mathrm{w} / \mathrm{v})$ agarose gel with ethidium bromide staining.

\section{CbrGAPDH expression under water stress}

In order to obtain plants under different conditions of watering we used $C$. brasiliense seeds from an Atlantic Forest located at Tiradentes-MG, Brazil. To accelerate the germination, we performed a slight groove at seeds epicarps prior sowing. Ten plants were well watered (control treatment) and ten plants had watering interrupted at 5 months of age (drought treatment). After 42 days, two leaves of each plant were water potential measured (Pressure Chamber PMS 1000 Instruments, Corvallis, OR, USA) and leaves from five plants in both conditions (control and drought) were collected, mixed and macerated in liquid nitrogen to RNA isolation (protocol

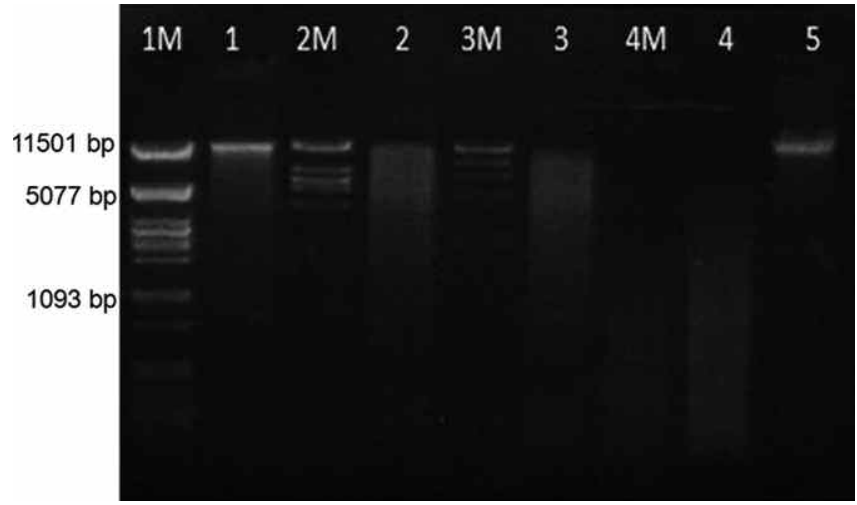

Figure 1. - Enzymatic manipulation of C. brasiliense DNA to assess quality. Total DNA leaf of $C$. brasiliense digested (5 $\mu \mathrm{g}$ ) with PstI (1), EcoRI (2), HindIII (3) and HinfI (4), as compared to digestion of $\lambda \mathrm{DNA}(5 \mu \mathrm{g})$ with the same enzymes (1M) PstI, (2M) EcoRI, (3M) HindIII and (4M) HinfI. C. brasiliense un digested DNA $(5 \mu \mathrm{g})$ is showed in lane (5).
3 ). All the subsequent steps to perform the expression analysis of $C b r G A P D H$ followed the protocols described in the present work.

\section{Results}

\section{DNA isolating}

Our protocol of DNA extraction, using $300 \mathrm{mg}$ of fresh material, results in yields of $107( \pm 3) \mu \mathrm{g}$ for leaves, 42 $( \pm 16) \mu \mathrm{g}$ for stems and $53( \pm 5) \mu \mathrm{g}$ for roots. These yields were obtained after the adaptation of FERREIRA and GRATTAPAGLIA's protocol. The original protocol previously tested resulted in very poor yield and quality, what made it unsuitable for further applications in molecular biology (data not shown). We increased the concentration of PVP and 2- $\beta$-mercaptoethanol for $2 \%$ and $1 \%$, respectively. The quality of the DNA was high $\left(\mathrm{A}_{260 / 280}\right.$ ranging of 1.88 to 2.02). To further check the quality the DNA of $C$. brasiliense, it was digested with four distinct restriction enzymes. The agarose gel analysis indicated that the DNA is also suitable for enzymatic manipulation (Fig. 1).

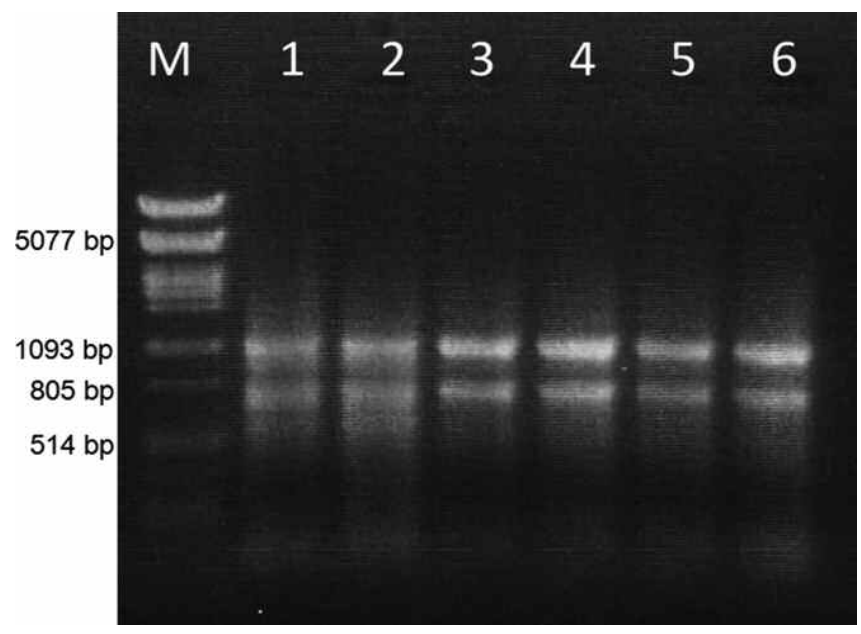

Figure 2. - Gel eletrophoresis analysis of RNA (1 $\mu \mathrm{g})$ from $C$. brasiliense extracted following the WANG et al. (2008) protocol. Leaf (lanes 1 and 2), stem (lanes 3 and 4) and root (lanes 5 and 6 ). The gel was visualized in $1 \%$ agarose gel and staining with ethidium bromide. M: $\lambda$ DNA digested with PstI.

Table 1. - Yield and purity of C. brasiliense total RNA extracted from different tissues (leaf, stem and root). Data represent mean and SE of 2 biological replicates.

\begin{tabular}{lcccc}
\hline Protocol* & Tissue & \multicolumn{2}{c}{ RNA Purity } & Yield \\
& & $\mathrm{A}_{260 / 280}$ & $\mathrm{~A}_{260 / 230}$ & $(\mu \mathrm{g} / 100 \mathrm{mg})$ \\
\hline (1) RNAeasy® (Qiagen) & Leaf & $1.77 \pm 0.06$ & $0.77 \pm 0.02$ & 0.65 \\
& Stem & $2.12 \pm 0.27$ & $0.22 \pm 0.14$ & 0.15 \\
& Root & $1.96 \pm 0.44$ & $0.14 \pm 0.04$ & 0.18 \\
\hline (2) Trizol®) (Invitrogen) & Leaf & $1.55 \pm 0.08$ & $0.09 \pm 0.02$ & 0.48 \\
& Stem & $1.67 \pm 0.08$ & $0.09 \pm 0.04$ & 0.46 \\
& Root & $1.76 \pm 0.13$ & $0.10 \pm 0.05$ & 0.55 \\
\hline (3) Invisorb (Invitek) & Leaf & $2.09 \pm 0.04$ & $1.84 \pm 0.07$ & 26.5 \\
& Root & $2.12 \pm 0.01$ & $1.82 \pm 0.05$ & 14.05 \\
\hline (4) Wang et al. 2008* & Leaf & $1.89 \pm 0.01$ & $1.89 \pm 0.01$ & 5.94 \\
& Stem & $2.07 \pm 0.01$ & $2.05 \pm 0.03$ & 1.7 \\
& Root & $2,02 \pm 0.04$ & $1.97 \pm 0.02$ & 1.43 \\
\hline
\end{tabular}




\section{RNA isolating}

The RNA quality obtained by Trizol ${ }^{\circledR}(1)$ and RNeasy ${ }^{\circledR}$ Plant Mini Kit (2) procedures was unsatisfactory triggering problems even for agarose gel analysis, indicating excessive contamination. The low ratio $\mathrm{A}_{260 / 280}$ of the RNA samples from Trizol ${ }^{\circledR}$ and RNeasy ${ }^{\circledR}$ Plant Mini Kit procedures suggest contamination by polysaccharides or phenols. The protocols (3) and (4) resulted in better yields of RNA (Table 1). The main change included at Wang's protocol (4) may have helped to achieve better yields was the extraction buffer incubation time which was prolonged for 15 minutes. This change resulted in clear supernatant and also a clear-cut peak at $260 \mathrm{~nm}$ that indicates RNA samples with low amounts of contaminating proteins, polysaccharides and polyphenolic compounds. Then, clearly visible band for $28 \mathrm{~S}$ and $18 \mathrm{~S}$ ribosomal RNA (rRNA) were observed on gel electrophoresis analysis indicating that such protocol preserved the RNA during the extraction without degradation (Fig. 2).

\section{Gene Cloning and Sequencing}

A 376-bp fragment of the $G A P D H$ gene was amplified by RT-PCR using the degenerated primers which were designed based on alignment of nine homologues which were accessed at GenBank NCBI as follow: Populus

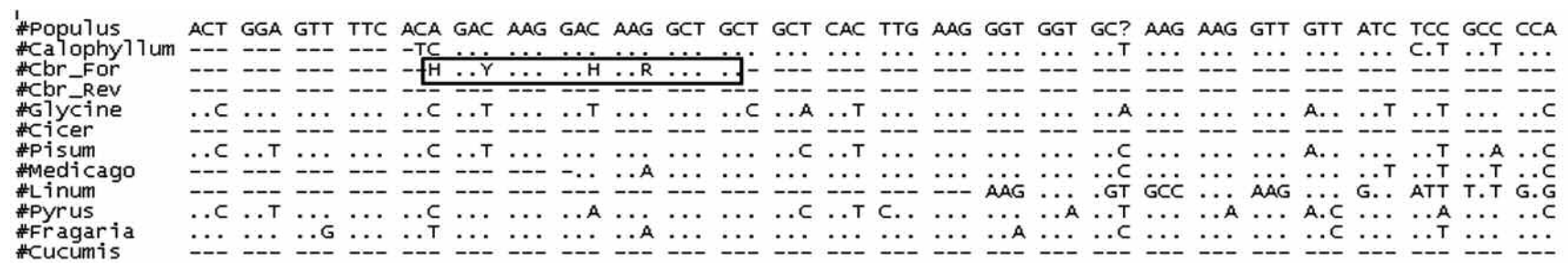

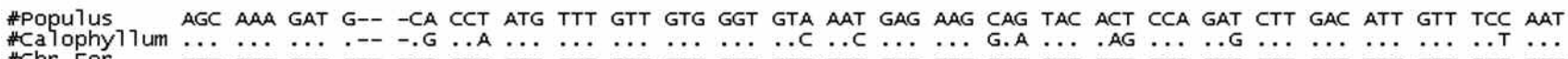
\#Cbr_For \#GTycine \#Cicer \#Pisum \#Linum \#Pyrus \#Fragaria

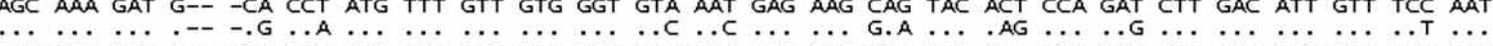

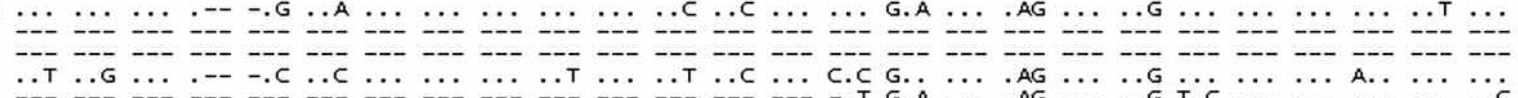

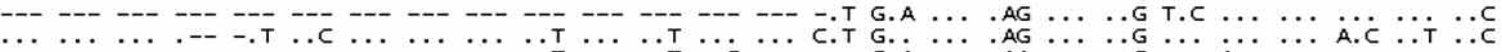

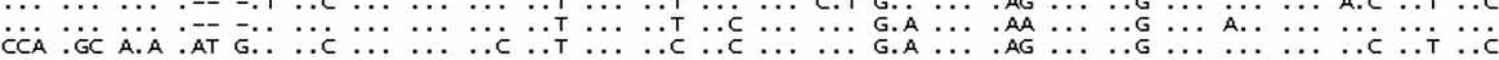

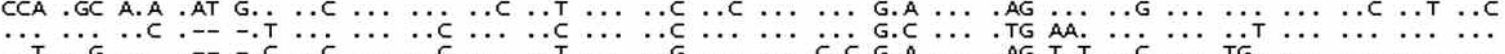

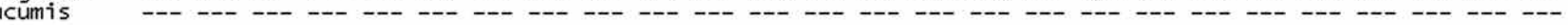

\#Populus GCT AGC TGC ACT ACC AAC TGT CTT GCC CCC TTG GCC AAG GTT ATC CAT GAC AGG TTT GGA ATT GTT GAG GGT CTT ATG

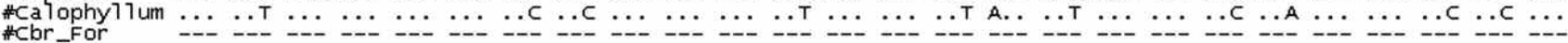
\#Cbr_Rev \#Cicer \#Pisum * inum *Pyrus Fragaria \#Cucumis

\#Populus ACT ACA GTT CAC GCG ATT ACT GCC ACT CAG AAA AC- TGT TGA TGG TCC ATC AAT GAA GGA CTG GAG AGG TGG AAG GGC

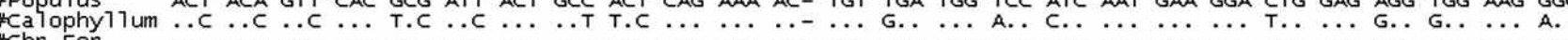
\#Cbr_For \#Cbr-Rev \#Glycine \#cicer \#Medicago \#L inum Pyrus \#Fragaria

\#Popu7us

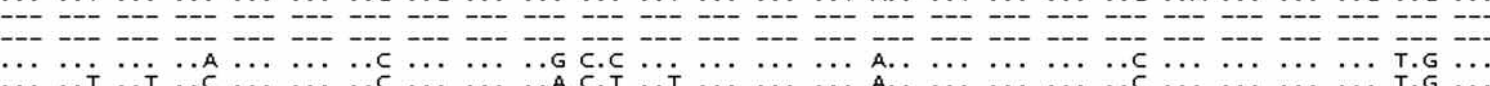

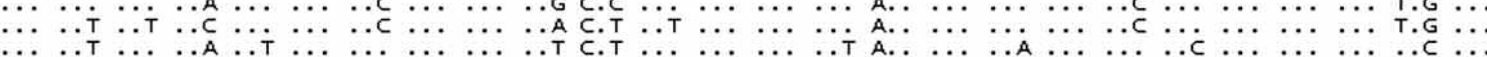

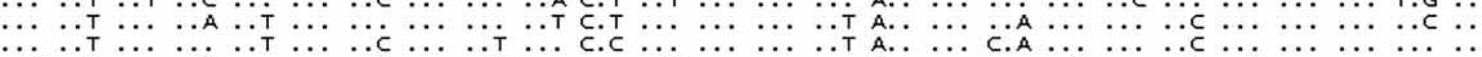

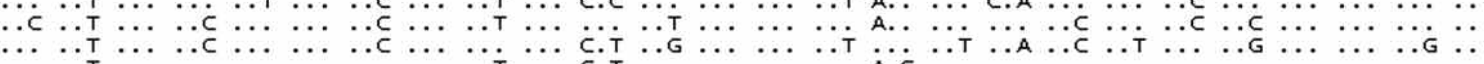

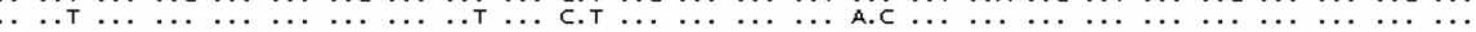
\#Cbr_For *Cbr_Rev - Gyycin \#-Cicer *Pisum \#Medicag * Linum *Pyrus Fucumis

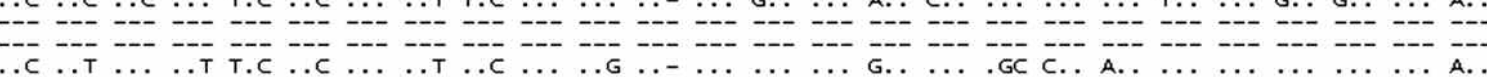

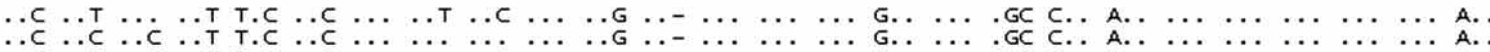

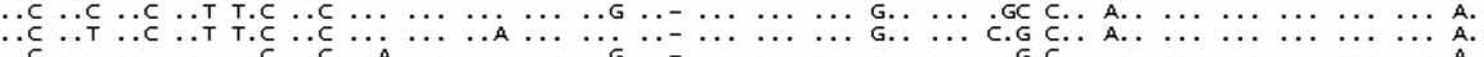

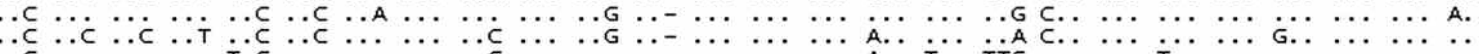

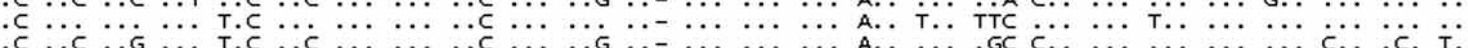
TGC TTC CTT CAA TAT CAT TCC TAG CAG CAC TGG GGC TGC CAA GGC TGT TGG aAA GGT TCT GCC aGC ACT TAA TGG aAA \#Populus \#Cbr_For \#Cbr-Rev \#-Gycine \#-Cicer medicago *Linum tPyrus \#Fragaria

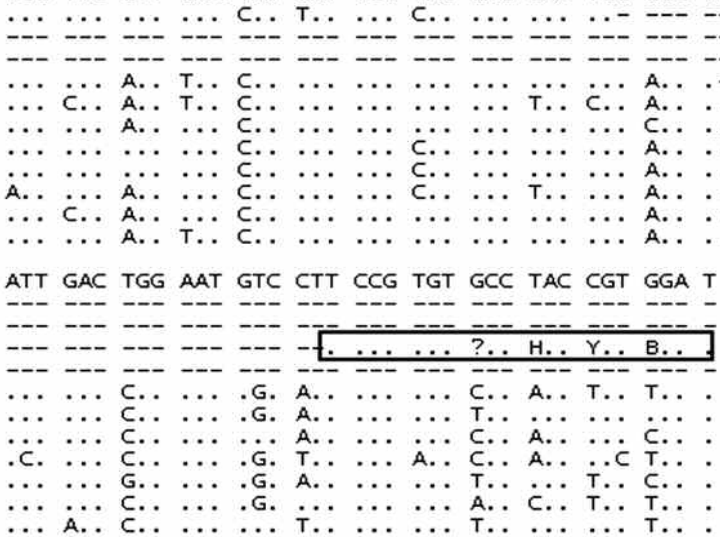

Figure 3. - Placement of phylogenetic informative indels in the aligned sequences from representatives taxa. Sequences correspond to the nine putative orthologues of CbrGAPDH (Calophyllum) aligned using CLUSTAL W. Dashes represent alignment gaps; dots indicate the same nucleotide as the reference Populus (DQ173770.1). The black boxes indicate the primers sequences: Cbr_For indicates the forward sequence and Cbr_Rev indicate the reverse sequence of degenerate primers. 


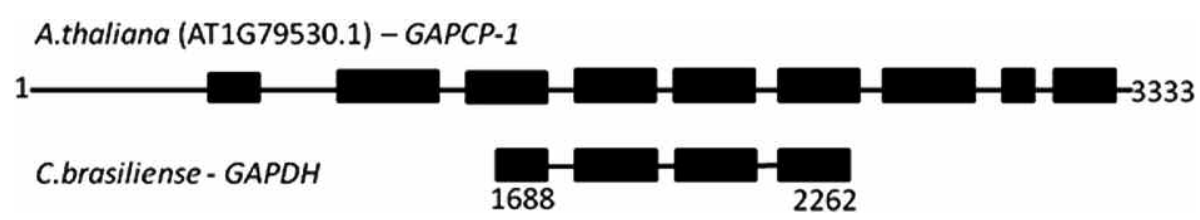

Figure 4. - Representation of putative C. brasiliense GAPDH gene (CbrGAPDH) organization based on the comparison with GAPCP-1 from A. thaliana by alignment. The black boxes represent the exons and the continuous line represents the introns. The numbers at $C$. brasiliense scheme are positions related to the $A$. thaliana full length genomic sequence $($ size $=3,333 \mathrm{bp})$.

maximowiczii $\times$ Populus nigra (DQ173770), Glycine max (EU741646.1), Cicer arietinum (AJ010224.1), Pisum fulvum (EU269889.1), Medicago sativa (EF526095.1), Linum usitatissimum (AJ623267.1), Pyrus pyrifolia var. culta (AB266450.1), Fragaria $\times$ ananassa (AB363963), Cucumis melo (AB033600.1) (Fig. 3). We selected these sequences according to the classification of species within eurosid group. The sequence analysis showed that the deduced amino acid sequence of $C$. brasiliense has high similarity to other GAPDHs reported. Among the GAPDH in GenBank, Nicotiana attenuata DQ682459.1 and Nicotiana langsdorffii $\times$ Nicotiana sanderae EF636821.1 has the highest identities (85\%) when compared as C. brasiliense. Putative conserved domains from NADB Rossman and Gp dh_C superfamilies were detected on $C$. brasiliense $G A P D \bar{H}$ protein sequence (data not shown). The structure of $G A P D H$ gene from $C$. brasiliense was compared to the GLYCERALDEHYDE-3-PHOSPHATE DEHYDROGENASE OF PLASTID 1 gene from Arabidopsis thaliana (At1G79530.1) available at TAIR Database. We aligned the $C$. brasiliense sequence obtained in this work with both full genomic and CDS sequences from Arabidopsis in order to visualize the exons and introns regions of this gene. The strategy was the alignment of three sequences (two from Arabidopsis plus one from C. brasiliense), which showed correspondence between exons of C. brasiliense and Arabidopsis (Fig. 4).

\section{Reverse transcription polymerase chain reaction (RT-PCR)}

RT-PCR reaction was performed using GAPDH primers to check the RNA quality for enzymatic manipulation and the potential of this gene as housekeeping in gene expression analysis. Transcripts of the expected size were obtained demonstrating that the protocols used were suitable for gene expression analyses. PCR products were observed from 30 cycles when the cDNA was the template for the three plant tissues (Fig. 5). The

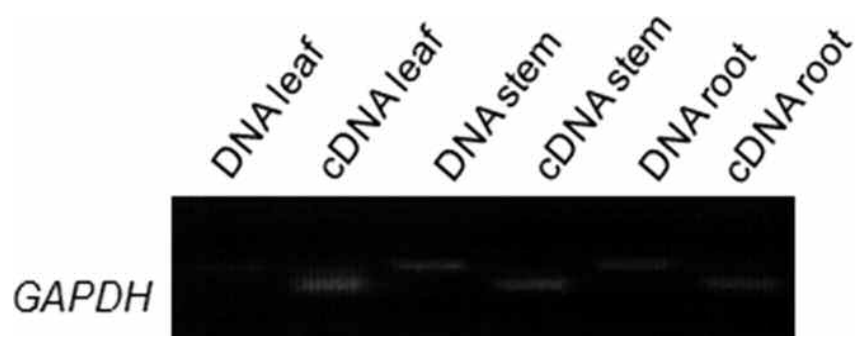

Figure 5. - RT-PCR expression analysis of $C b r G A P D H$ gene in leaves, stems and roots of $C$. brasiliense. Genomic DNA was used as PCR control. different size between the products of amplification from DNA and cDNA is result of intron region in the C. brasiliense genomic DNA as expected by the comparative analysis with Arabidopsis gene structure (Fig. 4). Primer pairs that differentiate between genomic and cDNA are highly recommended for RT-PCR expression studies because can indicate genomic DNA contamination in cDNA preparations.

The expression levels of GAPDH from C. brasiliense $(C b r G A P D H)$ were comparable among samples of the distinct tissues tested, could provide evidence that this gene can be a good reference to RT-PCR analysis. In order to provide further evidence of the gene expression stability of $\mathrm{CbrGAPDH}$, we compare it expression in well watered plants $(\Psi=-1.04 \pm 1.5 \mathrm{MPa} ; \mathrm{n}=10)$ and plants which were not watered during 42 days $(\Psi=-5.34 \pm 0.09 \mathrm{MPa} ; \mathrm{n}=10)$. The drastic effects of the drought stress in the development of the $C$. brasiliense root system (Fig. $6 b$ and $c$ ) did not result in differences in $C b r G A P D H$ gene expression (Fig. 6a).
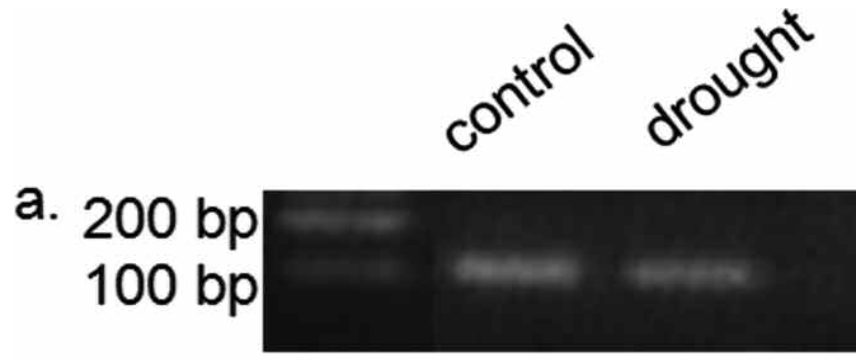

b.

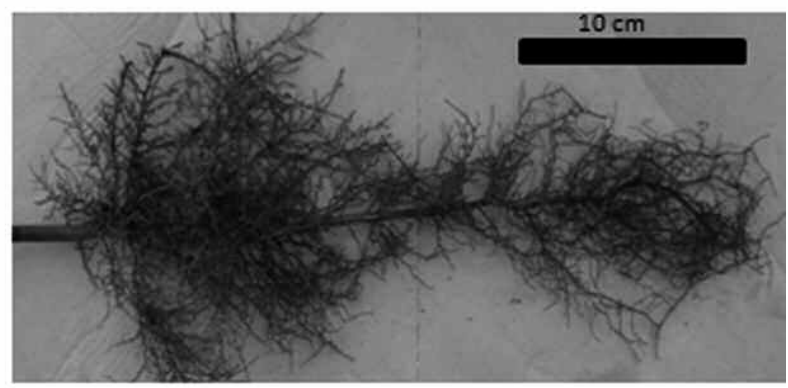

C.

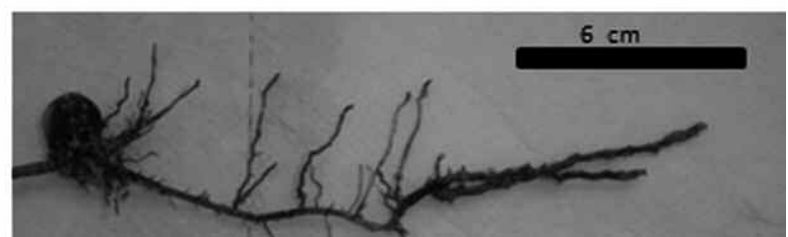

Figure 6. - Expression analysis of $C b r G A P D H$ by RT-PCR in roots watered and root under drought stress (47 days after stop watering). $1 \mathrm{~Kb}$ ladder (Invitrogen) was loaded on the left lane (a); Root development of $C$. brasiliense under regular watering (b) and under drought stress $(c)$. 


\section{Discussion}

The modifications implemented in this work for the DNA isolation to reduce the effects of oxidation with phenolic compounds and to protect the DNA from peroxidases and poliphenolidases (FERREIRA and GRATTAPAGLIA, 1995) contributed for the $C$. brasiliense DNA integrity. Since the high $\mathrm{NaCl}$ concentration of the buffers helps to remove polysaccharides (CHANG et al., 1993), we used $\mathrm{NaCl} 1.4 \mathrm{M}$ on CTAB precipitation buffer instead of EDTA/Tris-HCl, employed in the FERREIRA and GRATTAPAGLIA's protocol. In summary, the modifications described in here were essential to allow isolation of gold-standard quality genomic DNA for enzymatic manipulation from $C$. brasiliense tissue samples.

The protocols Trizol ${ }^{\circledR}(1)$ and RNeasy ${ }^{\circledR}$ Plant Mini Kit (2) have been used successfully to isolate RNA from leaf tissue in several plants such as Arabidopsis (AlvEsFERREIRA et al., 2007), tobacco (MEISEL and LAM, 1996) and maize (DAS et al., 1990). Since most of the successful plant RNA isolation procedures use these two procedures, we decided to test them in C. brasiliense. However, these two traditional procedures resulted in poor yields and low quality RNA for all tissues tested on C. brasiliense. Inadequate results were also achieved with commercially available extraction kits, such as RNeasy $^{\circledR}$ and Trizol ${ }^{\circledR}$, to RNA extraction of medicinal plants that are rich in secondary metabolites (GHANGAL et al., 2009). Problems with RNA or DNA extraction of wild plants or wood plants are due to impurities such as terpenes, polyphenolics, and polysaccharides, which are often abundant in these plants and coextract with DNA or RNA. As a consequence, many tree or wild species require more complex extraction methods than do annual or crop plants (SHEPHERD et al., 2002). We suggest, for RNA isolation of $C$. brasiliense, the Invisorb ${ }^{\circledR}$ Spin Plant RNA Mini Kit (Invitek) or the method described here adapted from WANG et al. (2008). The main difference between the WANG's method and our protocol is the extended period in extraction buffer, which greatly increased the suspension of the tissue helping the RNA extraction. However, this procedure is time consuming and, all together, the procedure requires a large quantity of start material. The Invisorb (Invitek) method (3) combines the advantages of being fast, easily applicable to different tissues. Although, it can be expensive if a large amount of samples need to be prepared.

The strategy for cloning genes by the employment of degenerated oligos has been proved reliable and promising for exotic species with poor genomic information. However, the degeneracy parameter in the oligonucleotide design and the optimization at PCR cycles are critical for success (JABADO et al., 2006; LÖFFERT et al., 1998). The method described here was successful to isolation of the first cloned gene of $C$. brasiliense, the $C b r G A P D H$. The identification of the CbrGAPDH gene will have important applications in quantifying of expression levels of genes selected from functional genomics studies in $C$. brasiliense. The GAPDH gene can be also used as reference gene to perform quantitative real-time RT-PCR, a powerful tool to investigate relevant changes in gene expression in plants (CRUZ et al.,
2009; ARTICO et al., 2010). However, it is always important to check the potential of $C b r G A P D H$ as reference gene when a new experimental condition is tested.

Our results showed for the first time the successful application and adaptation of protocols to extract RNA and DNA from the rain forest wood plant $C$. brasiliense and the isolation of the $C b r G A P D H$ gene, a reference gene for expression analysis. The development of these tools is the first step in the characterization of C. brasiliense by molecular genetics techniques. Therefore, it will be very useful for those interested to employ it as a model for ecogenomic of rain forest trees. Moreover, this work illustrated the steps necessary for building the essential framework for molecular genetics research in exotic plants with poor genomic information.

\section{Acknowledgments}

This work was supported by The State of Rio de Janeiro Research Fundation (FAPERJ), as part of the program Pensa-Rio - Apoio ao Estudo de Temas Relevantes e Estratégicos para o Estado do Rio de Janeiro, with the project: "Biodiversidade molecular, morfofisiologia e expressão gênica em resposta ao estresse abiótico em Calophyllum brasiliense, uma espécie da Mata Atlântica com interesse ecológico e madeireiro". This work was supported by the Conselho Nacional de Desenvolvimento Científico e Tecnológico CNPQ and the Fundação Carlos Chagas Filho de Amparo à Pesquisa do Estado do Rio de Janeiro - FAPERJ.

\section{References}

Alves-Ferreira, M., F. Wellmer, A. P. Banhara, V. Kumar, J. L. Riechmann and E. M. Meyerowitz (2007): Global expression profiling applied to the analysis of Arabidopsis stamen development. Plant Physiol 145: 747-762. DOI: 10.1104/pp.107.104422.

Artico, S., S. M. Nardeli, O. Brilhante, M. F. GrossiDe-SÁ and M. Alves-FerReIra (2010): Identification and evaluation of new reference genes in Gossypium hirsutum for accurate normalization of real-time quantitative RT-PCR data BMC Plant Biology 10: 49. DOI:10.1186/1471-2229-10-49.

Bozelli, R., F. A. Esteves and F. Roland (2000): Lago Batata - Impacto e recuperação de um sistema amazônico. IB-UFRJ/SBL, Rio de Janeiro, Brazil.

CARvalho, P. E. R. (1994): Espécies florestais brasileiras: recomendações silviculturais, potencialidades e uso da madeira. EMBRAPA/CNPAF, Colombo.

Chang, S., J. Puryear and J. Cairney (1993): A simple and efficient method for isolating RNA from pine trees. Plant Mol Biol Rep 11(2): 113-116. DOI: 10.1007/BF02670468.

Claros, M. G. and F. M. CÁnovas (1998): Rapid high quality RNA preparation from pine seedlings. Plant Mol Biol Rep 16 (1): 9-18. DOI: 10.1023/A:1007473906327.

Cruz, F., S. Kalaoun, P. Nobile, C. Colombo, J. Almeida, L. M. G. Barros, E. Romano, M. F. Grossi-De-SÁ, M. VASLIN and M. ALVES-FerREIRA (2009): Evaluation of coffee reference genes for relative expression studies by quantitative real-time RT-PCR. Mol Breeding 23 (4): 607-616. DOI: 10.1007/s11032-009-9259-x. 
Das, O. P., C. Álvarez, S. Chaudhuri and J. Messing (1990): Molecular methods for genetic analysis of maize. Methods Mol Cell Biol 1: 213-222.

Dean, J. D., P. H. Goodwin and T. Hsiang (2002): Comparison of Relative RT-PCR and Northern Blot Analyses to Measure Expression of $\beta-1,3$-Glucanase in Nicotiana benthamiana Infected With Colltotrichum destructivum. Plant Molecular Biology Reporter 20: 347-356. DOI: $10.1007 / \mathrm{BF} 02772122$.

Duarte, H. M., A. Gebler, F. R. Scarano, A. C. Franco, E. A. DE Mattos, M. Nahm, H. Rennenberg, P. J. F. P. Rodrigues, H. L. T. ZaluaR and U. LÜTTGE (2005): Ecophysiology of six selected shrub species in different plant communities at the periphery of the Atlantic Forest of SE-Brazil. Flora 200: 456-476.

Dubos, C., G. Le-Provost and D. Pot et al. (2003): Identification and characterization of water-stress-responsive genes in hydroponically grown maritime pine (Pinus pinaster) Seedlings. Tree Physiol 23: 169-179. DOI 10.1093/treephys/23.3.169.

Feder, M. E. and T. Mitchell-Olds (2003): Evolutionary and ecological functional genomics. Nature Reviews in Genetics 4: 651-657. DOI:10.1038/nrg1128.

FERREIRA, E. F. and D. GRATTAPAGLIA (1995): Introdução ao Uso de Marcadores Moleculares RAPD e RFLP em Análise Genética. $2^{\text {nd }}$ ed. EMBRAPA-CENARGEN, Brasília, $220 \mathrm{pp}$.

Fischer, E. and F. A. M. Dos Santos (2001): Demography, phenology and sex of Calophyllum brasiliense (Clusiaceae) trees in the Atlantic Forest. J. Trop. Ecol. 17: 903-909. DOI: 10.1017/S0266467401001675.

Gasic, K., A. HeRnandez and S. S. Korban (2004): RNA Extraction From Different Apple Tissues Rich in Polyphenols and Polysaccharides for cDNA Library Construction. Plant Mol Biol Rep 22: 437a-437g. DOI: 10.1007/BF02772687.

Ghangal, R., S. Raghuvanshi and P. C. Sharma (2009): Isolation of good quality RNA from a medicinal plant seabuckthorn, rich in secondary metabolites. Plant Physiology and Biochemistry 47: 1113-1115. DOI: 10.1016/j.plaphy.2009.09.004.

GonzÁlez-MartíneZ, S. C., K.V. KRUtovsky and D. B. NEALE (2006): Forest-tree population genomics and adaptive evolution. New Phytologist 170 (2): 227-238. DOI: $10.1111 /$ j.1469-8137.2006.01686.x.

HoLL, K. D. (1998): Effects of above- and below-ground competition of shrubs and grass on Calophyllum brasiliense (Camb.) seedling growth in abandoned tropical pasture. For Ecol Manage 109: 187-195. DOI 10.1016/S0378-1127(98)00248-5.

Iskandar, H. M., R. S. Simpson, R. E. Casu, G. D. BonNETT, D. J. MACLEAN and J. M. MANNERS (2004): Comparison of Reference Genes for Quantitative Real-Time Polymerase Chain Reaction Analysis of Gene Expression in Sugarcane. Plant Molecular Biology Reporter 22: 325-337. DOI: 10.1007/BF02772676.

JaBADO, O. J., G. PalaCios, V. KaPOOR, J. Hui, N. RENWICK, J. ZHAI, T. BRIESE and W. I. LIPKIN (2006): Greene SCPrimer: a rapid comprehensive tool for designing degenerate primers from multiple sequence alignments Nucleic Acids Research 34 (22): 6605-6611. DOI: 10.1093/nar/gkl966.

Kiselev, K. V. and A. S. Dubrovina (2010): A new method for analyzing gene expression based on frequency analysis of RT-PCR products obtained with degenerate primers. Acta Physiol Plant 32: 495-502. DOI: 10.1007/s11738-009-0426-9.
KING, R. T. (2003): Succession and micro-elevation effects on seedling establishment of Calophyllum brasiliensis Camb. (Clusiaceae) in an Amazonian River meander forest. Biotropica 35: 462-471. DOI: 10.1111/j.17447429.2003.tb00603.x.

KumAR, S., K. TAMURA and M. NeI (2004): MEGA3: Integrated software for Molecular Evolutionary Genetics Analysis and sequence alignment. Brief Bioinform 5: 150-163.

Küpper, H., L. O. Seib, M. Sivaguru, O. A. Owen and L. V. KochIAN (2007): A method for cellular localization of gene expression via quantitative in situ hybridization in plants. The Plant Journal 50: 159-175. DOI: 10.1111/j. 1365-313X.2007.03031.x.

LÖFfert, D., N. SEIP, S. Karger and J. KANG (1998): PCR optimization: degenerate primers. Qiagen News 2: 3-6.

Martin, R. C, V. G. Hollenbeck and J. E. Dombrowski (2008): Evaluation of reference genes for quantitative RT-PCR in Lolium perenne. Crop Science 48 (5): 1881-1887. DOI: 10.2135/cropsci2007.10.0597.

Meisel, L., B. Fonseca, S. González，R. Baezayates, V. Cambiazo, R. Campos, M. Gonzalez, A. Orellana, J. Retamales and H. Silva (2005): A rapid and efficient method for purifying high quality total RNA from peaches (Prunus persica) for functional genomics analyses. Biol Res 38: 83-88. DOI: 10.4067/S071697602005000100010.

MeISEL, L. and E. LAM (1996): The conserved ELKhomeodomain of KNOTTED-1 contains two regions that signal nuclear localization. Plant Mol Biol 30: 1-14. DOI: 10.1007/BF00017799.

Neale, D. B. and O. Savolainen (2004): Association genetics of complex traits in conifers. Trends Plant Sci. 9: 325-30. DOI:10.1016/j.tplants.2004.05.006.

Oliveira-Filho, A. T. and J. A. RATTER (1995): A study of the origin of central Brazilian forests by the analysis of plant species distribution patterns. Edinb J Bot 52: 141-194.

OMAR, W. S. W., L. B. Willis and C. RHA et al. (2008): Isolation and utilization of acetyl-coa carboxylase from oil palm (Elaeis guineensis) mesocarp. Journal of Oil Palm Research, 97-107.

Reid, K. E., N. Olsson, J. Schlosser, F. Peng and S. T. LUND (2006): An optimized grapevine RNA isolation procedure and statistical determination of reference genes for real-time RT-PCR during berry development. BMC Plant Biology 6: 27. DOI:10.1186/1471-2229-6-27.

Scarano, F. R., K. T. Ribeiro, L. F. D. Moraes and H. C. LiMA (1997): Plant establishment on flooded and unflooded patches of a freshwater swamp forest in southeastern Brazil. J Trop Ecol 14: 793-803.

Shepherd, M., M. Cross, R. L. Stokoe, L. J. Scott and M. E. JONES (2002): High-Throughput DNA Extraction From Forest Trees. Plant Molecular Biology Reporter 20: 425a-425j. DOI: $10.1007 / \mathrm{BF} 02772134$.

TANG, R., C. LI, K. XU, Y. H. DU and T. XIA (2010): Isolation, Functional Characterization, and Expression Pattern of a Vacuolar $\mathrm{Na}+\mathrm{H}+$ Antiporter Gene TrNHX1 from Trifolium repens L. Plant Molecular Biology Reporter, 28 (1): 102-111. DOI: 10.1007/s11105-0090135-y

WANG, X., W. Tian and Y. Li (2008): Development of an efficient protocol of RNA Isolation from recalcitrant tree tissues. Mol Biotechnol 38 (1): 57-64. DOI: 10.1007/ s12033-007-0073-6. 